\title{
Adopting Indonesian Folklore as an Instructional Media through Cards Games
}

\author{
Komang Redy Winatha ${ }^{1}$, Ni Putu Suci Meinarni ${ }^{2}$, Ayu Gede Willdahlia ${ }^{3}$ \\ 1,2,3 Department of Informatic Engineering, STMIK STIKOM Indonesia, Denpasar, \\ Bali - Indonesia
}

Received: September 30, 2020 Revised: December 23, 2020 Accepted: January 8, 2021

\begin{abstract}
Psychologically, humans tend to love games compared to learning. Therefore, learning should be delivered through fun ways and not boring just like a game. This research aims to develop card games as learning media of Interpersonal Skill Course at STMIK STIKOM Indonesia. This course was chosen based on the availability of minimum teaching materials, the level of material abstractness which is high enough, and there is still no innovative learning that can support the learning. Beside easing the students in comprehending the materials of Interpersonal Skill through fun ways, this card game at once also reminds the students about deep philosophy contained in Indonesian folklores. The chosen folklores cover the stories developing and frequently told in the society such as Timun Emas, Malin Kundang, and so on. The research design used research and development method referring to ADDIE model which is limited until the developing stage. The result of this research is learning media the card game which is an innovation in learning process replacing conventional learning. Based on the results of expert test conducted, the learning media in the form of card games adopting Indonesian folklores is valid and successfully developed.
\end{abstract}

Keywords: Innovative media, fun learning, 7 habits, folklore, local wisdom

(*) Corresponding Author: $\quad$ redywin@stiki-indonesia.ac.id

How to Cite: Winatha, K.R., Meinarni, N.P.C., \& Willdahlia, A.G. (2020). Adopting Indonesian folklore as an instructional media through cards games. Jurnal Teknologi Pendidikan, 22 (3): 209-219. http://dx.doi.org/10.21009/jtp.v22i3.17428

\section{INTRODUCTION}

Human life in accordance with its development is very much affected by the renewal that occurs around it. As nowadays, the aspects of human life are influenced by technological advancement in all fields such as economic, social, cultural, even in education. It can be said that the advancement of technology goes equally with the advancement of knowledge so that the more knowledge develops, the more technology develops. Behind all of the simplicity provided include facilitating communication and access to information seeking, there are negative impacts caused especially on the cultural aspects (Nasution, 2017). The impact is a lack of public interest, especially teenager towards the cultural heritages, one of them is folktale. Folktale can be interpreted as stories that originated and developed in society inherited from generation to generation through oral speech (Jayapada, Gegana; Faisol; Kiptiyah, 2017). In Indonesia, there are various folktale which intended to deliver the moral message in various regions. For example, Timun Emas, Malin Kundang, Bawang Merah Bawang Putih, and so on. These folktales contain values of local wisdom and morals that can be used as a communication medium 
to teach educational values about life to the society (Gusnetti, 2016). Presently, folktale has begun to be less desirable because it is considered irrelevant to the development of globalization era that is all modern and advance. Therefore, it is necessary to spread the folktale through lecturers as educators to embed and maintain the local values to the students.

The right effort that can be done is by inserting the folktales in main subject of learning. The right course for that is interpersonal skills. Interpersonal skill is a compulsory subject that must be taken by students at STMIK STIKOM Indonesia, which in its teaching gives a concept of self-development based on an understanding of how humans can live effectively, in both career and family (Hamdan, 2003). Seven of these habits include (Covey, 2015): (1) Be proactive, this habit is called as principles of personal vision, because it is concerning to the change of personal vission about self and environment; (2) Begin with the end in mind, this habit is called as principles of personal leadership, because with two habits, individual is able to direct theirselves towards power from inside; (3) Put first things first, this habit is known as principles of personal management, because this habit gives individual ability to define matters and make priority; (4) Think win/win, this habit is called as principles of interpersonal leadership, because it is concerning a broader leadership dimenssion than for self, but personally; (5) Seek first to understand, then to be understood, this habit is called as principles of empathic communication, because it is concerning any attitude and behavior of empatic personal communication; (6) Synergize, this habit is known as principles of creative communication, because it is related to the individual ability that can create a creative teamwork situation in personal communication; and (7) Sharpen the saw, this habbit is called as principles of balanced self-renewal, or balanced self-renewal principals, which is a habit related to self-renewal that must be done continuously in a balanced manner by individu in any dimenssion.

The reason for choosing this course is because the interpersonal skill is subject in character education and folktale contains many ethical and moral values that can support character education itself. However, there were several obstacles found in the implementation of learning interpersonal skills during observations. First, the time given is still less, seeing that the object is heavy and abstract. Second, the availability of teaching objects are minimum, and there is no innovative learning media that can support learning. This is not in line with the curriculum demands which requires lecturers to be creative in developing the learning models. Third, in its implementation, the lecturer only presents what is in the book and only focuses on the completeness of the subject contained in the curriculum without seeing the expected learning result. Thus, it is necessary to develop an interpersonal skill subject learning media that is collaborated with folktale and mixed in the form of a game called game-based learning. Game-based learning is a system that is applied in the education process, where the users (lecturers) can adopt a game for the cognitive interest and learning motivation (Vusić, Bernik, \& Geček, 2018). The choice of this strategy, based on the ability of the game to increase motivation, effectiveness and learning results (Liu \& Chen, 2013),(Noviyanti, 2018) also basically whether young or old, people likes games. Using a game approach in the learning process, provide interactivity, collaboration with study partners and active students in the learning activities (Mardati \& Wangid, 2015). Game-based learning media can also develop learning motivation in the aspects of relevance, attention, self-confidence, and satisfaction (Cahyana, Paristiowati, Nurhadi, \& Hasyrin, 2017). Inspired by the uno card game, this media modified the appearance, game rules, and relate it to the Indonesian folktales to the course obtained in interpersonal skills subject learning. The implementation of local wisdom values in a learning medium can develop students' awareness and character based on local wisdom values (Hetarion, Hetarion, \& Makaruku, 2020). 
The development of this media is important because it is an innovative media as a supporting medium in interpersonal skills subject learning that is able to develop students' socialization skills. The use of card media provides a more pleasant situation and triggers the students to think critically (Sukri \& Indriani, 2017) also to respect the Indonesia's cultural heritage.

\section{METHODS}

The development model used is ADDIE, an approach that helps in design and development of learning products (Aldoobie, 2015). This model consists of five development stages, that are: analyze, design, development, implementation and evaluation. The choice of this model is based on the consideration of the ADDIE model presented in a simple and systematic way if it is compared to the other design models. Because it is simple and systematically structured, makes the ADDIE model os very easy to use and apply (Cheung, 2016). In this study, the stages conducted were limited to the stages of analysis, design, and development.

Analysis Stage. In this stage, the developer defines the problem, identifies the source of the problem, and determines the possible solutions from the problem (Muruganantham, 2015). In the initial stage a descriptive analysis was conducted consisting of some activities. First, couse analysis. This activity was done to find out the needs necessary for the subjects that were used as the development object. The information is obtained by conducting interviews to the lecturer of the course. Second, analysis of basic competencies and indicators. Analyzing basic competencies, and learning results indicators based on the curriculum structures and course syllabus. Third, analysis of the learning environment. Analyzing the learning environment has the purpose to know how the student learning environment is. The learning environment analyzed includes the convenience of the study room and the learning support facilities. In this stage the data was obtained through interviews and observations to the students and lecturers. The results of the analysis, then used as consideration material in developing media adjusted to the existing conditions before proceed to the next stage. Based on the analysis results, it was determined that the subjects which were the object of the study was interpersonal skill with samples of STMIK STIKOM Indonesia students. The determination of objects, samples, research location is based on conditions that enable the trials to be done.

Design Stage. The activities done in this stage are: (a) choosing the delivery message form; (b) designing the evaluation instruments. The instruments used in measuring the success of media development are in the form of competency test questionnaires and learning achievement tests; (c) material mapping with folktales; and (d) designing the cards to make the developers are easier to understand the subject presentation designs. The results obtained in the design stage include product evaluation instruments, material mapping, and card design which are then used as references or outlines in the next stage that is the development stage (development).

Development Stage. The development is conducted based on the design stage that has been planned previously. The activities conducted at the development stage are: (a) material collection. The type of material collected, adjusted to the characteristics and needs of the material; (b) media making. The making of the media is done based on the systematics that have been planned at the design stage; (c) independent testing. At this stage, the products that have been developed then tested independently by the developers. 
This test is conducted to find out the mistakes such as in material writing until the sequence mistakes and placement of supporting components illustration in the form of pictures. The test method used is the black box method; (d) distribution. The distribution stage is the phase where development products that have been tested, reproduced and distributed to users for evaluation. There are three activities in the distribution stage, that are: 1) making guidelines, 2) making cards, 3) making packaging and 4) doubling; and (e) experts trial. The data in the trial were obtained using a questionnaire instrument to determine the quality of the media that developed. The results of these expert's trial are input for revisions so that at the end, a valid product is obtained. The products have been through a series of expert trials, then analysis and revision before proceeding to the next stage which is the implementation stage.

\section{RESULTS \& DISCUSSION}

\section{Results}

The analysis phase has three steps including subject analysis, basic competency analysis, and learning environment analysis. The skill which develop the most is interpersonal skill. Interpersonal skill is obliged thing that must have in all of study programs of STMIK STIKOM Indonesia. This course has been chosen because the lack of learning resources used and the lack of innovative learning media to learn about this skill. Based on the interview of interpersonal skill lecturer, the learning resources used in the college is 7 Habits of Highly Effective People book by Stephen R. and the source of material took from internet only. Students do not have a structured guidance of learning material such as printed modules, worksheets, or other teaching media such as independent learning media which help students in the learning process. The second step is analyzing on the basis of competencies and indicators of learning outcomes based on the syllabus. The material presented on card media is adapted to the principles in the 7 Habits concept such as (1) proactive life as a personal vision, (2) start with the potrayal of final life, as a form of personal leadership, (3) ability of prioritizing. These three habits are things that individuals need to meet effective life (internal conditions). In addition, an individual still has to solve challenges to live effectively by (4) win-win solutions to find out the interpersonal leadership, (5) understanding people first, and then discuss with other, and (6) synergizing, effective and creative conversation to produce third alternative. Effective human habits have habit of (7) self-upgrading. All abilities number 1 to 6 is less meaningful if not accompanied by a willingness to upgrade themselves. The third step is the analysis of learning environment, and the STMIK STIKOM Indonesia as example. The learning environment can determine what around student learning places that oppose behavior and developments in learning both directly and indirectly (Aini \& Taman, 2012). Based on observations made at STMIK STIKOM Indonesia, it can be learned about the learning environment that occurs as relatively comfortable and free from consideration. Classroom is a good place as the learning process. Room arrangement and air circulation are very good, providing comfort for students while in class both in lecture hours and break time. Supporting learning support facilities such as projectors, computers, speakers, and libraries are also able to improve the process and motivation of students in learning. Regarding the learning environment, the main challenge found was the lack of teaching media participation as supporting learning. Students can only rely on material delivered by instructors as the main learning resources. It is interesting that the lecturers are less able to provide an interesting and adequate learning atmosphere for students. Until now, lecturers 
only rely on conventional methods of learning process. It definitely cannot encourage student activity and motivation in learning.

The design phase will be applied by several activities. Firstly, the form of message will be choosing. Fun learning can help students to understand the material provided and actively participate in the learning process that make better understanding of material itself, so that the form of delivery of the selected message is to play assisted by media cards. The second activity is designing evaluation instruments. The instrument used in measuring the success of media development is in the form of expert test questionnaires and learning achievement tests. The expert test questionnaire made consisted of: questionnaire for content experts, media experts, and learning design experts. Third activity is mapping material using folklore. It is important to know the general picture of folklore to use and facilitate design development. At this stage, the supporting elements presented in each competency are structurally organized to meet the learning objectives. The fourth activity is designing cards to make the development of material presentation design easier and identify which materials must be made, obtained, or compiled with predetermined concept.

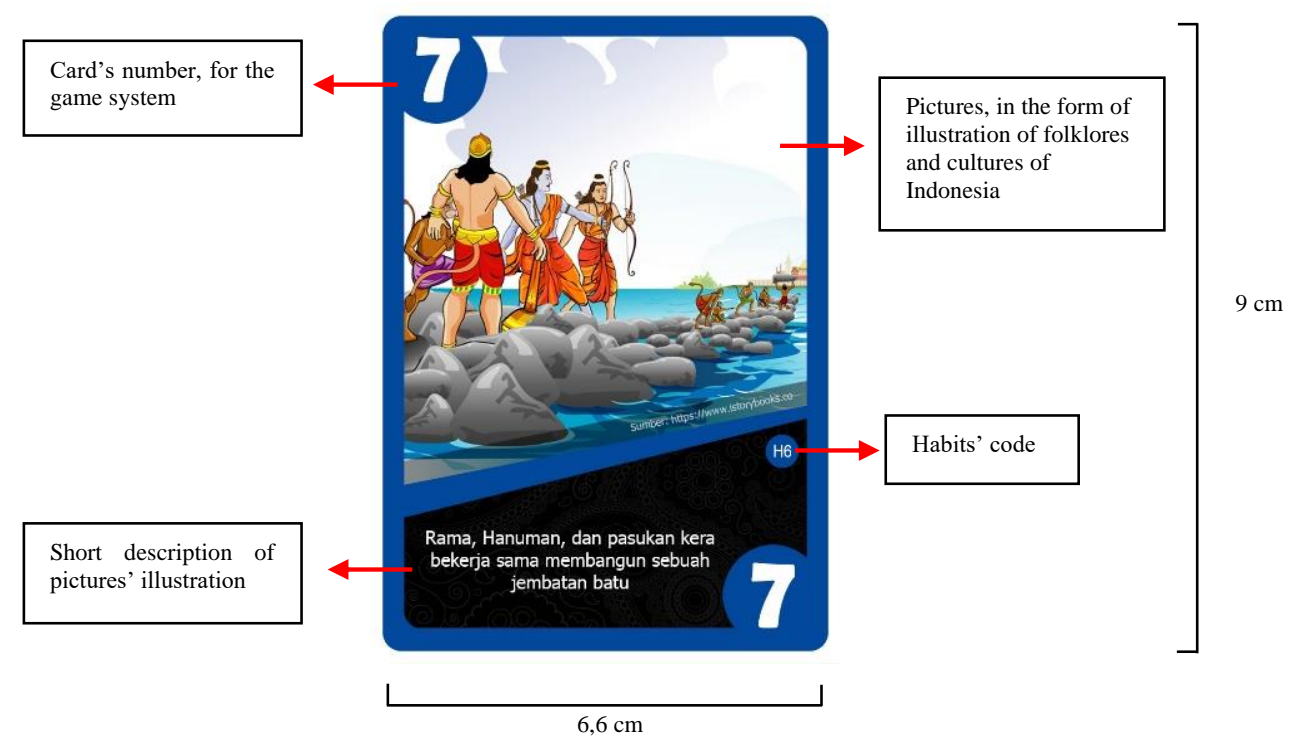

Figure 1. Siki Card Design

The development stage is a stage that required components are arranged into a unit based on their functions. Development is carried out based on the design phase plan. The activities of development phase: Firstly, collecting the material. Materials are collected, adapted to characteristics and needs of learning materials. Supporting components in delivering material are text and images/graphics. Text is the easiest stored and recognized form also has a simple structure. The things which have to be concern with in text are: a) text style, b) size, c) space, d) color, and 5) capital letters. Text style uses plain text which has no edges in the text. The font used is the sans serif type Calibri. The text size used is 12 pt. Text space is adjusted so the lines are not too close and far. The majority text color used is white with black as background to support the reading process. After that, the image/graph is the media that makes the forming information easier to understand. Image is one of the important components in learning media because it can summarize and present complex data and convey many words. Images used as explanations of material which has text in presentation. Second phase is making the media. The overall design of the media card is made using Adobe Photoshop software. Figure 1 shows an appearance of media card. 
The final product development is a set of 111 cards namely siki. The word siki comes from Balinese which has meaning "one". The card consists of 8 different colors, and each color represents each habit (there are 7 habits and 1 paradigm). These are the rules of the game:

1. Give seven cards to each player and place the rest of the cards face down in the center of the table. This card stack is referred to as a drink card.

2. Open the first card. The first card is taken from a closed stack. Put the card right in front of all players. The open card could be any card.

3. Put one of your cards in the waste pile if your turn arrives. Your card must have a number, color (habit), or writing that is the same as a card in a pile of waste unless you have a Wild card. If you have this card, you can choose the color of the card to be played.

4. Read the habit written on the card. If the card has a different habit, then the player must read the habit written on the card before show it to other players. Other players will guess which habit is read in class of habit. The player who first guesses correctly will move 1 of his choice cards into a stack of closed cards.

5. Continue the game in a circular order. The beginning of the game takes place in a circular sequence in a clockwise direction. The direction of the order can be change if there is a player who issued a card that can change the direction of the order.

6. Shout "Siki !!" When the card that is owned is only 1 sheet left, then the card owner must call "Siki !!" before the other players. If not, the card owner must take 1 card from the closed stack.

7. The game is over. The game will end if the card in the closed stack has run out. Calculate the total score of the card still in hand. The player with the highest score, he is the loser.

Third phase, testing independently. At this stage, the products will be tested independently by the developers themselves. This test aims to find various errors in writing words and images used by players. Fourth phase is the distribution. The distribution phase is the stage where development products that have been tested, reproduced and distributed to users as the framework of evaluation. There are three activities in the distribution phase: a) guidance, b) packaging, and c) doubling the media card. Fifth phase is product testing. At this stage, testing done by review from experts included: content, design, and media experts.

1. Content expert. The results of the development in the form of card games along with the guidebook were reviewed by a content expert who mastered particularly in interpersonal skills courses. The content expert examines the subject matter, whether or not the presentation of teaching material with the competencies required by the curriculum and syllabus. In addition, content experts also provide input on writing structure and language style. It purposes to avoid the incorrect presentation of material and it is expected that material content is easily understood by students.

2. Learning design experts. Take part in reviewing: 1) aspects of learning design; 2) strategy on how to deliver messages; and 3) display design. The focus in testing aspects of learning design is the formulation of competencies, presentation of content, ways of learning, and the assessment methods used

3. Media experts. Media experts examine the feasibility and suitability of media objects that will be used in teaching materials. This is including the suitability of image, as well as typography in the explanation material description, the way of media content presentation, the object displayed and the match of the types of multimedia objects with the learning goals. Media experts also review the technical issues and physical design of teaching materials, such as: easy to use, and final packaging of teaching materials. 
The media complete the series of expert tests including media, content and design experts. The test result of learning media experts includes: Firstly, the suitability of the selection of images in visualizing the material. The use of images can support learning experiences when the image is successfully focused on the students' attention visually and the material presented (Smeets \& Bus, 2015). Visual aids in the form of images can also provide support for the content of the material and can improve learning understanding (Shabiralyani, Hasan, Hamad, \& Iqbal, 2015). The use of images, selected and placed based on this following criteria: (1) the image must have high resolution, so the image not blurry; (2) the image placed near the text described (the principle of closeness according to Gestalt theory) to support students in processing information through text and images, so that cognitive processes are not separate; (3) the size of the image adapts to the size of the card, so that the distribution of text and images appears proportionally; (4) the address of sources from internet must be mentioned below illustrated images. This is to prevent copyright infringement. Secondly, the media is easy to use and has high flexibility. Thirdly, the media is packed with attractive designs and colors. The use of appropriate and attractive colors, helps students in increasing their attention on the material (Chang, Bo; Xu, 2018). Fourthly, the style, size, space and text color are consistent. The text uses a plain font in the sense that the letter does not have horizontal or vertical lines at its angles. The type of font used is a type of sans serif type Calibri. The Caliber type is chosen because it has complete variation better than the other types. The variations referred are bold, italic and underline. Meanwhile, the text size is 12pt and text space is adjusted so that the lines of text are not too close and far. This is intended to provide user convenience in reading card descriptions. Text color adjusted to the background color used. This means that if the color of the text used is dark then the background must use bright colors, and vice versa. The combination of text and background colors used mainly in material content is black and white. Fifth, usage guidelines are packed with interesting and practical visualizations. Practical aspects in the guide, manifested in the form of guidebook sizes adapted to packaging. This makes the guide and packaging of the card a whole unit. Guides are also presented with images that can support the understanding of users, especially lecturers in understanding how to use media.

The test results of learning design experts included: Firstly, the content, the material presented through the media related with the learning objectives. Secondly, from the aspect of content organizing strategy, the media contains repetition to strengthen understanding, trigger motivation, and images selected will make a better students' understanding. Thirdly, from the aspect of content delivery, the material presented through the media is very simple and clear, the abstract ideas is more concrete, presented innovatively to generate interest and motivation, and supporting the involvement and willingness of students to be actively involved in expressing and sharing ideas. Fourthly, based on the attractiveness of the design, the appearance of the media is considered to be able to attract the interest and attention of students to learn. The appearance of display including colors, letters and images selection. The display design made as simple as possible. Fifth, based on game aspect, the media developed is easy to play, fun and provides a learning experience. There are several factors that influence ease of use, learn and become skilled (Nurlifa, Kusumadewi, \& Kariyam, 2014). Based on the test, there are no difficulties experienced by users in using media.

The result of content expert's assessment included: Firstly, from the aspect of coverage and accuracy of the material, the material presented through the media included material in the curriculum, the breadth of material based on the basic competencies and indicators, and illustrations used in the form of material. Secondly, from the aspect of productivity and innovation, the media developed fosters curiosity, encourages the desire to find more information, is student-centered, stimulates involvement and participation, 
presents examples of local wisdom through folklore and daily experiences, and stimulate students to think critically, creatively, and innovatively in solving problems. Thirdly, from the aspect of presentation, messages conveyed through media are easily understood. In addition, the incorporation of interpersonal skill material with Indonesian folklore is very useful to broaden readers' horizons and enrich the content of the media because it not only conveys the subject matter but also other important information that must be known. Fourthly, the material is delivered using language in everyday conversation. Simple and interesting writing can give the impression that the user communicates directly with the teaching material. In addition to language factors, writing patterns also influence reading comprehension. Material in the media, using patterns that remain in writing. This is done referring to the opinion conveyed by Tompkins (Tompkins, 2010), which states that students will recognize important ideas and information better when they understand the writing pattern in material presentation.

\section{Discussion}

Indonesia is a big country which consists of thousands of islands. With vast geographical conditions, so it is not surprising that Indonesia has many cultural diversities which even many have not yet been documented and abandoned by the community because it is considered less attractive in modern and advanced times like today. Of the many cultural riches in Indonesia, one that needs to be considered is its sustainability is part of literary culture, namely folklore. Basically folklore is a belief, legend, and the customs of a nation that has existed for a long time, passed down through generations both orally and in writing. In folklore, it contains a lot of moral values education that must be instilled, among others: 1) individual moral norms, such as: obedience, courage, sacrifice, 2) social moral values, such as: working together, compassion, 3) religious values, such as: believe in God and his power, be patient (Jamilah, 2017), (Juanda, 2019). As one part of culture, folklore lives and belongs to the people of the past who are guarded for generations. If this cultural heritage is continuously left without serious attention, it is not surprising that someday a generation of "forget culture" will be born. Efforts to install a love of literary culture must continue to be encouraged to attract the interest of the younger generation to want to glance at their own culture in creative and innovative ways. One effort to start growing awareness and ownership of the culture is through education. Education is the most effective form of cultural strategy to build a culture by creating a good society, and building a human civilization in harmony with humanitarian ideals (Zafi, 2017). Therefore, we must preserve and preserve culture by incorporating cultural elements in education, so that the output of education is not only knowledge but also readiness in social life. When discussing culture, it is certainly very boring for most students. The solution, is to develop fun learning media that adopts all the positive effects of a game.

Games like two sides of a coin. On the one hand, games are seen as an entertainment medium that causes addiction and affects a person's lifestyle, even the most extreme ones can affect mental, social and negative behavior (Suplig, 2017). On the other hand, games can be seen as a learning medium and on the same side offer addiction. This is related to the nature of the game that is challenging, addictive and fun. Such considerations provide opportunities as well as challenges, how to use the game as a learning media that is not only entertaining, influencing, but also providing information and education. The learning process in a game environment, allows students to try various challenges, and accept risk directly from every action and initiative they do (Hidayat, 2018). All the potential possessed by a game makes it possible to use it as a motivational learning media for students. His ability to influence the cognitive and emotional aspects of the user together it can be a force as a learning medium (Lakoro, 2009). 
Seeing this phenomenon, one of the creative efforts in answering this challenge is to create creative and innovative learning media through games. Siki is card games designed to provide students with an understanding of interpersonal skills courses while introducing and re-learning cultural values through folklore. The card contains illustrated images accompanied by a brief description that explains the scene. Through this game, students can not only learn material 7 habits and socialize with opponents to play in a way that is fun, but also can capture the message implied in folklore and relate it to matter. This fun learning experience will certainly have an impact on students' interests and motivations. Student interest and motivation are increasing, will trigger curiosity and then lead to further exploration and more depth of what they have done (Chin \& Effandi, 2015).

The use of media is not limited to lecture hours but can also be used outside of lecture hours. In line with that, in addition to attracting media, it must also be able to overcome the limitations of study time in class, so that it can be used both inside and outside the lecture hours. Here are some of the advantages of the media created: (1) The print quality of the media is clear and can be read by the user; (2) Media cards are designed with attractive images and colors to reduce boredom in learning; (3) Media cards can be used inside or outside lecture hours; (4) Providing new learning experiences to students; and (5) Reintroducing Indonesian folklore along with the ethical values contained in it to students.

The weaknesses of the media developed are as follows: (1) There are still many folktales that have not been inserted in the media; (2) Almost all images used are obtained from the internet, so it needs to be involved graphic designers to produce original images; (3) The effectiveness and effect on motivation and learning achievement have not been tested; (4) Lecturers must be able to condition the class so that there is no noise due to the media is game based; and (5) Requires a long time allocation if used in learning.

\section{CONCLUSION}

The problem raised in this development research is the process delays interpersonal skills learning at STMIK STIKOM Indonesia because lack of availability of innovative learning media, lack of time allocation provided, the material presented by the lecturer is still done conventionally, and only focus on completing the material contained in the curriculum without regard to results expected learning. To achieve this problem, lecturers need to improve learning patterns by seeking an innovation in activities learning. One alternative is to develop learning media in the form of siki card game. This media combines material interpersonal skills, namely the principle basic principles 7 habits with Indonesian folklore. Based on the results of the expert test, the media developed are said to be valid from aspects of content, learning design, and media and feasible to continue in the next stage, namely the implementation and evaluation stages to find out the influence of the media on student motivation and learning outcomes. The suggestions that can be given for the development of the results of this study are (a) limited developed products up to the development stage, suggested other researchers to study further until the evaluation stage to find out media effectiveness when applied in the learning process; (b) Development the media, only includes STMIK STIKOM Indonesia interpersonal skills courses. For other researchers who want to develop similar media, to develop it on other courses; and (c) It is expected that all lecturers in the course interpersonal skills, can implement this media in the learning process. 


\section{ACKNOWLEDGEMENT}

We thank to Lembaga Pengembangan Inovasi dan Kreativitas (LPIK) and Lembaga Penelitian dan Pengabdian kepada Masyarakat (LPPM) STMIK STIKOM Indonesia which has supported this research both mentally and financially. We also express our gratitude to Mr. I Dewa Made Krishna Muku, M.T. and Dr. Ketut Agustini, S.Si., M.Si. who have been willing to take the time to become content, design and learning media experts.

\section{REFERENCES}

Aini, P. N., \& Taman, A. (2012). Pengaruh Kemandirian Belajar Dan Lingkungan Belajar Siswa Terhadap Prestasi Belajar Akuntansi Siswa Kelas XI IPS SMA Negeri 1 Sewon Bantul Tahun Ajaran 2010/2011. Jurnal Pendidikan Akuntansi Indonesia, 10(1), 4865. https://doi.org/10.21831/jpai.v10i1.921

Aldoobie, N. (2015). ADDIE Model Analysis phase. American International Journal of Contemporary Research. https://doi.org/10.13140/2.1.4687.6169

Cahyana, U., Paristiowati, M., Nurhadi, M. F., \& Hasyrin, S. N. (2017). Studi Tentang Motivasi Belajar Siswa Pada Penggunaan Media Mobile Game Base Learning Dalam Pembelajaran Laju Reaksi Kimia. JTP-Jurnal Teknologi Pendidikan, 19(2), 143-155.

Chang, Bo; Xu, R. W. (2018). The Impact of Colors on Learning. Adult Education Research Conference 2018, 0-6. New Prairie Press.

Cheung, L. (2016). Using the ADDIE Model of Instructional Design to Teach Chest Radiograph Interpretation. Journal of Biomedical Education, 2016, 1-6. https://doi.org/10.1155/2016/9502572

Chin, L. C., \& Effandi, Z. (2015). Effect of Game-Based Learning Activities on Children 's Positive Learning and Prosocial Behaviours. Jurnal Pendidikan Malaysia, 40(2), 159-165. https://doi.org/10.17576/jpen-2015-4002-08

Covey, S. C. (2015). The 7 Habits of Highly Effective People (7 Kebiasaan Manusia yang Sangat Efektif). Dunamis Publishing.

Gusnetti, D. (2016). Struktur dan Nilai-Nilai Pendidikan dalam Cerita Rakyat Kabupaten Tanah Datar Provinsi Sumatera Barat. Jurnal Penelitian Bahasa Dan Sastra Indonesia. https://doi.org/10.22202/JG.2016.v2i1.1408

Hamdan, Y. (2003). Penerapan Konsep " 7 Habits of Highly Effective People " dalam Profesi Dosen. Mediator, 4(1), 119-134.

Hetarion, B. D. ., Hetarion, Y., \& Makaruku, V. (2020). Implementasi Pendidikan Karakter Berbasis Kearifan Lokal Cuci Negeri dalam Pembelajaran IPS. Jurnal Teknologi Pendidikan, 22(1), 1-12.

Hidayat, R. (2018). Game-Based Learning: Academic Games sebagai Metode Penunjang Pembelajaran Kewirausahaan. Buletin Psikologi, 26(2), 71-85. https://doi.org/10.22146/buletinpsikologi.30988

Jamilah. (2017). Pembentukan Karakter Anak melalui Pembelajaran Cerita Dongeng Nusantara. Jurnal PTK Dan Pendidikan, 3(2), 87-96.

Jayapada, Gegana; Faisol; Kiptiyah, B. M. (2017). Kearifan Lokal dalam Cerita Rakyat sebagai Media Pendidikan Karakter untuk Membentuk Literasi Moral Siswa. Bibliotika: Jurnal Kajian Perpustakaan Dan Informasi, 1(2), 60-62. https://doi.org/10.15713/ins.mmj.3

Juanda. (2019). Nilai Pendidikan dalam Cerita Rakyat dan Peranannya terhadap Pembentukan Karakter Siswa. LINGUA - Jurnal Bahasa, Sastra, Dan Pengajarannya, 15(2), 161-179. 
Lakoro, R. (2009). Mempertimbangkan Game Edukasi. Seminar Nasional ITS, pp. 6-8.

Liu, E. Z. F., \& Chen, P.-K. (2013). The Effect of Game-Based Learning on Students' Learning Performance in Science Learning - A Case of "Conveyance Go." Procedia - Social and Behavioral Sciences, 103(2013), 1044 - 1051. https://doi.org/10.1016/j.sbspro.2013.10.430

Mardati, A., \& Wangid, M. N. (2015). Pengembangan Media Permainan Kartu Gambar Dengan Teknik Make a Match Untuk Kelas I Sd. Jurnal Prima Edukasia. https://doi.org/10.21831/jpe.v3i2.6532

Muruganantham, G. (2015). Developing of E-content package by using ADDIE model. Ijar.

Nasution, R. D. (2017). Effect of The Development of Communication Information Technology on Local Cultural Existence. Pengaruh Perkembangan Teknologi Informasi Komunikasi Terhadap Eksistensi Budaya Lokal.

Noviyanti, G. V. (2018). Pengaruh Game Based Learning terhadap Hasil Belajar Mata Pelajaran Ekonomi Kelas X SMA. 6(2), 110-115.

Nurlifa, A., Kusumadewi, S., \& Kariyam. (2014). Analisis Pengaruh User Interface Terhadap Kemudahan Penggunaan Sistem Pendukung Keputusan Seorang Dokter. Prosiding SNATIF Ke-1 Tahun 2014.

Shabiralyani, G., Hasan, K. S., Hamad, N., \& Iqbal, N. (2015). Impact of Visual Aids in Enhancing the Learning Process Case Research : District Dera Ghazi Khan . Journal of Education and Practice, 6(19), 226-234.

Smeets, D. J. H., \& Bus, A. G. (2015). The interactive animated e-book as a word learning device for kindergartners. Applied Psycholinguistics. https://doi.org/10.1017/S0142716413000556

Sukri, Y. F., \& Indriani, F. (2017). Pengembangan Media Permainan Kartu Gambar Dengan Teknik Think Pair Share Pada Siswa Kelas 3 Sekolah Dasar Di Palopo. 7(3), $168-172$.

Suplig, M. A. (2017). Pengaruh Kecanduan Game Online Siswa SMA Kelas X Terhadap Kecerdasan Sosial Sekolah Kristen Swasta Di Makassar. Jurnal Jaffray.

Tompkins, G. E. (2010). Literacy for the 21st Century: A Balanced Approach, 5th Edition. Pearson.

Vusić, D., Bernik, A., \& Geček, R. (2018). Instructional Design in Game Based Learning and Applications Used in Educational Systems. Technical Journal, 1(2), 11-17.

Zafi, A. A. (2017). Transformasi Budaya melalui Lembaga Pendidikan (Pembudayaan dalam Pembentukan Karakter). SOSIOHUMANIORA, 3(2), 105-112. 